\title{
INTEGRATED MODELS OF DIAMOND FORMATION AND CRATON EVOLUTION
}

\author{
Steven B. Shirey ${ }^{1}$, Stephen H. Richardson ${ }^{2}$ and Jeffrey W. Harris ${ }^{3}$ \\ ${ }^{1}$ Department of Terrestrial Magnetism, Carnegie Institution of Washington, 5241 Broad Branch Rd., NW, Washington, DC \\ 20015, USA; ${ }^{2}$ Department of Geological Sciences, University of Cape Town, Rondebosch 7701, South Africa; ${ }^{3}$ Division of \\ Earth Sciences, University of Glasgow, Glasgow G12 8QQ, UK
}

\section{INTRODUCTION}

An important goal of studies of Archean continents is to relate the age and composition of peridotite, eclogite, and diamonds to the geological processes of craton creation and assembly. For southern Africa, regional patterns of diamond composition and episodes of diamond growth can now be explained with models of cratonic lithosphere creation, stabilization and modification by using these disparate data sets: 1) decades of research on diamonds from major diamond mines, 2) application of the Re-Os isotopic system to age determinations of peridotites, eclogites, and sulfide inclusions in diamond, 3) high-accuracy thermochronometry of the lower crust, and 4) a new seismic pictures of the lithosphere.

\section{OBSERVATIONS}

\section{SEISMIC STRUCTURE}

The Kaapvaal-Zimbabwe craton is marked by relatively high P-wave velocity lithospheric mantle that occurs in two prominent but irregularly shaped lobes separated by a broad west-northwest trending band of relatively lower velocity mantle (Fig.1). Kimberlites distributed across southern Africa have diamonds that derive from mantle with differences in seismic velocity (Fig. 2).

\section{DIAMOND AGE}

Data on single E-Type sulfides from the De Beers Pool, Jwaneng, Koffiefontein, and Orapa collectively form a ${ }^{187} \mathrm{Re} /{ }^{188} \mathrm{Os} \mathrm{vs}{ }^{187} \mathrm{Os} /{ }^{188} \mathrm{Os}$ data array that has significant scatter about a circa 2.9 Ga age slope (Pearson et al., 1998; Richardson et al., 2001; Shirey et al., 2001; Shirey et al., 2003). Inclusions from the De Beers Pool show the tightest $2.9 \mathrm{Ga}$ line while the other diamond suites fall around this age but with more scatter. In three localities (De Beers Pool being the exception), there are two generations of sulfide inclusions: an Archean, circa $2.9 \mathrm{Ga}$ age suite and a Proterozoic suite with an age matching the Proterozoic silicate inclusion age. The circa $2.9 \mathrm{Ga}$ age is not resolvable from the ReOs model ages obtained on mantle peridotites (Carlson et al., 1999; Carlson et al., 2000; Irvine et al., 2001).

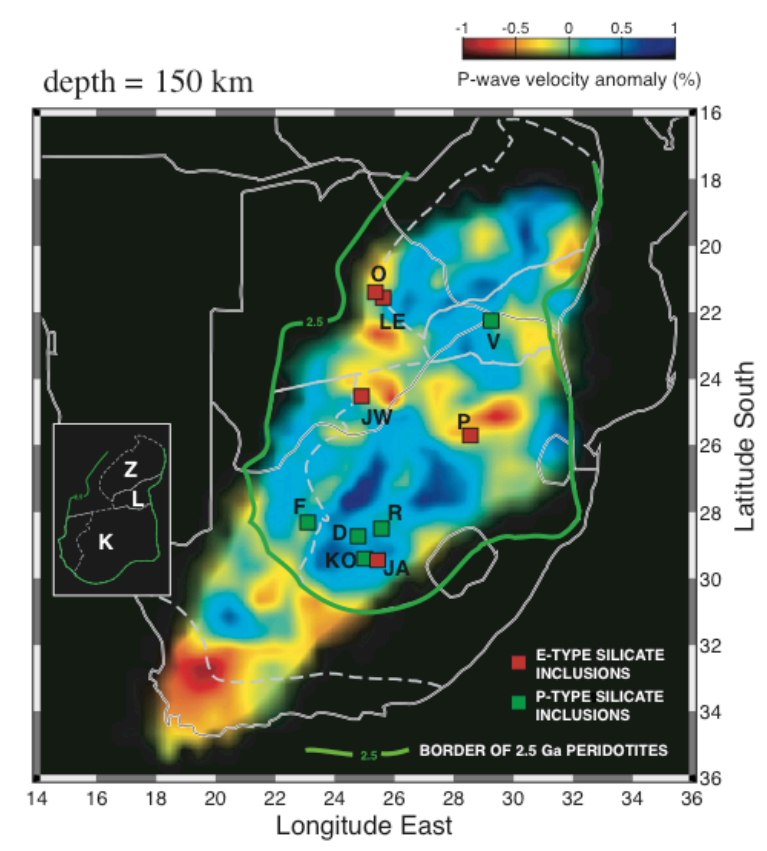

Figure 1. Tomographic image of the lithospheric mantle derived from seismic P-wave data at a depth of $150 \mathrm{~km}$ (James et al., 2001; James and Fouch, in press). The color scheme depicts \% deviation from an average cratonic lithosphere velocity model. Areal coverage spans the lithospheric mantle of the Kaapvaal $(\mathrm{K})$ and Zimbabwe $(\mathrm{Z})$ cratons and the Limpopo mobile belt (L; see inset, left). Bold green line indicates the outermost boundary of the Archean cratons. Diamond mines are shown by colored squares; red for those localities whose silicate inclusion suites are predominately eclogitic (Jagersfontein $=\mathrm{JA}$, Jwaneng $=\mathrm{JW}$, Letlhakane $=\mathrm{LE}$, Orapa $=\mathrm{O}$, Premier $=\mathrm{P}$ ) and green for those whose silicate inclusion suites are predominately peridotitic (Kimberley area mines of Wesselton, Bultfontein, and Dutoitspan termed De Beers Pool=D, Finsch=F, Koffiefontein $=\mathrm{KO}$, Roberts Victor $=\mathrm{R}$, and Venetia $=\mathrm{V}$ ). Reprinted with permission from Shirey et al, 2002, Science, 297: 1683-1686. Copyright 2002 American Association for the Advancement of Science.

P-Type (harzburgitic) garnets from Finsch and De Beers Pool (Richardson et al., 1984) have the oldest 


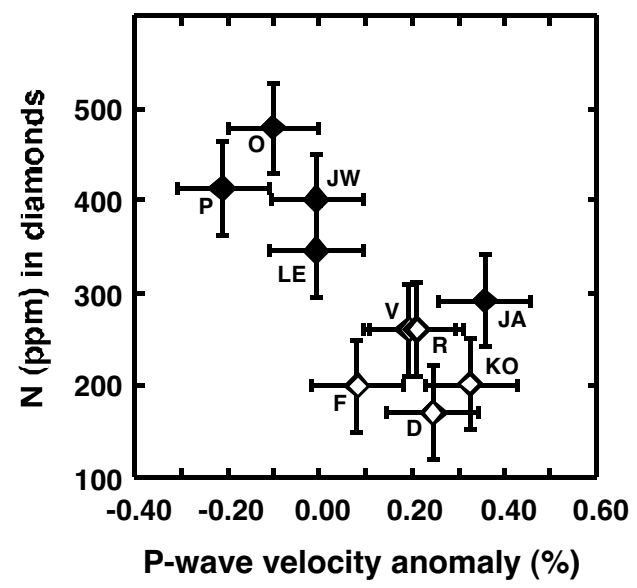

Figure 2. Average $\mathrm{N}$ abundance in diamonds versus $\mathrm{P}$-wave velocity anomaly. Error bars have been set at $\pm 50 \mathrm{ppm}$ for average $\mathrm{N}$ abundance, and $\pm 0.1 \%$ for P-wave velocity anomaly. Same lettering scheme as in Fig. 1. Peridotitic $=$ open symbols; eclogitic $=$ closed symbols. After Shirey et al. (2002).

model ages yet recorded for inclusions in diamond from southern Africa (Fig. 3). Premier P-Type (lherzolitic) garnets have a much younger isochron age $(1.9 \mathrm{Ga}$, Richardson et al., 1993) but an Archean (3.0 Ga) depleted mantle model age. All other southern African silicate inclusion suites dated with the Sm-Nd system (Richardson, 1986; Richardson et al., 1990; Smith et al., 1991; Richardson et al., 1999) are E-Types and yield Proterozoic isochron or model ages (Fig. 3).

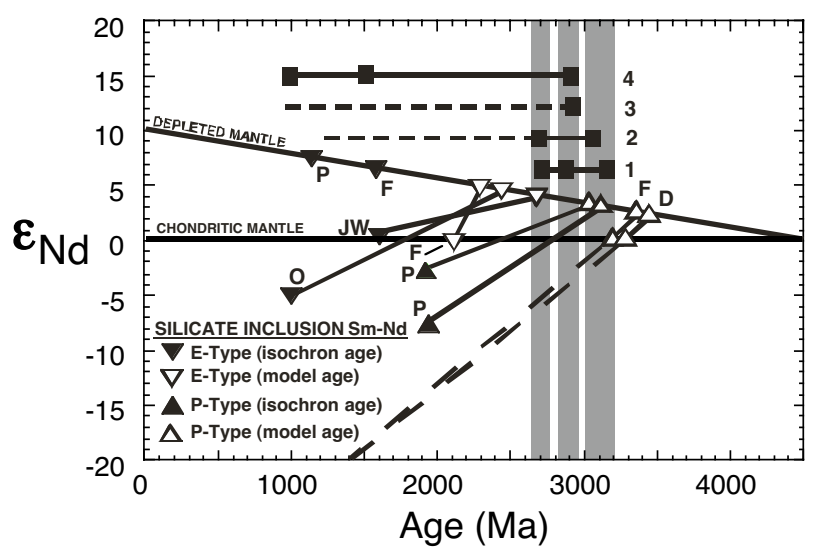

Figure 3. Sm-Nd isochron and model ages of silicate inclusions in diamond compared to the ages of major crust forming events in the Kaapvaal craton (1; Schmitz, 2002), peridotite xenolith Re-Os model ages (2; sources, cited in text), diamondiferous eclogite xenoliths (3; Shirey et al., 2001; Menzies et al., 2002), and sulfide inclusions in diamonds (4; sources cited in text). After Shirey et al. (2003).

\section{DIAMOND COMPOSITION}

Diamonds selected for $\mathrm{C}$ isotopic and $\mathrm{N}$ studies often provide a more representative diamond sample than those selected for age studies because they include both the P-Type and E-Type parageneses that are typically present at each locality. These undated diamonds reveal a large range in their $\mathrm{C}$ isotopic composition and $\mathrm{N}$ abundance. It has long been known (Sobolev et al., 1979) that diamonds of both P-Type and E-Type paragenesis show a prevalent mantle-like carbon isotopic composition $\left(\delta^{13} \mathrm{C}=-3\right.$ to $-7 \%$ ) with an isotopically light sub-population $\left(\delta^{13} \mathrm{C}=-10\right.$ to $\left.-34 \%\right)$, dominated by diamonds of E-Type paragenesis. Compiled data for the Kaapvaal-Zimbabwe cratons (Kirkley et al., 1991; Shirey et al., 2002; Shirey et al., 2003) adheres to this pattern.

Deines and coworkers $(1989 ; 1993$; 1997) previously noted the significantly higher $\mathrm{N}$ content of E-Type diamonds from Finsch, Jwaneng, Orapa, and Premier compared to their P-Type counterparts from the same kimberlite. This paragenesis versus diamond $\mathrm{N}$ content relationship extends to all ten kimberlites with wellstudied diamond populations (Fig. 2). The $\mathrm{N}$ content difference apparently does not lead to a significant difference in the aggregation state of $\mathrm{N}$ in Type Ia stones (Shirey et al., 2002; Shirey et al., 2003).

\section{DIAMOND AGE, COMPOSITION AND STRUCTURE OF THE MANTLE KEEL}

Kramers (1979) and Richardson (1984) first showed that diamonds are late- to mid- Archean, confirming that parts of the craton were underlain by mantle keel that could be as old as the oldest crust. Subsequent work of Richardson and coworkers (1986; 1990; 1993; 1999) on diverse eclogitic and lherzolitic silicate inclusions in diamonds produced Proterozoic ages suggesting a progression to more fertile silicate inclusion compositions with time. Recent Re-Os data show that all four of the eclogitic sulfide inclusion suites studied have late Archean ages that agree with late Archean Re-Os mantle model ages on cratonic peridotite (Carlson et al., 1999; Irvine et al., 2001; Shirey et al., 2001). The P-Type silicate inclusion model ages of 3.2-3.4 Ga, overlap some of the oldest crustal $\mathrm{U}-\mathrm{Pb}$ ages obtained in the western Kaapvaal craton (Moser et al., 2000; Schmitz, 2002) and predate many other materials in the lithosphere (Fig. 3).

The old, P-Type, harzburgitic silicate inclusions in diamonds from the De Beers Pool and Finsch were 
derived from seismically faster lithospheric mantle. The other P-Type silicate inclusion suite dated (Premier) which is lherzolitic and Proterozoic (Richardson et al., 1993), was derived from seismically slower mantle. All the other silicate inclusion suites dated so far are eclogitic, Proterozoic (Richardson, 1986; Richardson et al., 1990; Richardson et al., 1993; Richardson et al., 1999) and derived from seismically slower mantle. Sulfide inclusions from the four localities studied so far which are eclogitic, mostly Archean in age (Pearson et al., 1998; Richardson et al., 2001; Shirey et al., 2001), and derived from both fast and slow mantle. Of these four localities, De Beers Pool, with diamonds from seismically faster mantle, has the lowest percentage of Proterozoic inclusions.

Diamond paragenesis determines the pattern of $\mathrm{C}$ isotopic composition of diamond relative to lithospheric mantle seismic velocity. The frequency distribution of $\mathrm{C}$ isotope composition for E-Type diamonds appears nearly identical to that for diamonds from the seismically slow lithospheric mantle (Shirey et al., 2002). Additional complexities from Premier, Jagersfontein and Roberts Victor that are masked by the large number of specimens from Jwaneng and Orapa EType diamonds with $\mathrm{C}$ isotopic compositions less than $-9 \%$ (Shirey et al., 2003).

Nitrogen abundance also shows some correspondence with lithospheric seismic structure linked to paragenesis (Shirey et al., 2002; Shirey et al., 2003). Diamonds from Jwaneng, Letlhakane, Orapa, and Premier, the majority of which are eclogitic, have a higher percentage of Ia types and an average $\mathrm{N}$ content above $290 \mathrm{ppm}$, and were derived from seismically slower mantle. Diamonds from Koffiefontein, Finsch, Roberts Victor, Venetia and the De Beers Pool, the majority of which are peridotitic, have a lower percentage of Ia types and an average $\mathrm{N}$ content below $290 \mathrm{ppm}$, and were derived from seismically faster lithospheric mantle. The aggregation state of $\mathrm{N}$ in the Ia diamonds displays no clear systematic variation with lithospheric seismic velocity although De Beers Pool, Finsch and Roberts Victor diamonds from seismically fast mantle display the lowest percentages of aggregation to Bcenters (Shirey et al., 2002; Shirey et al., 2003).

\section{DIAMOND FORMATION AND CRATON EVOLUTION}

The current lithospheric seismic structure of the craton is interpreted to be a mid-Proterozoic overprint to a predominantly 2.9-3.4 Ga keel as evidenced by the occurrence of inclusions and xenoliths of both Archean and Proterozoic age in the same or closely-spaced kimberlites from seismically slow lithosphere (e.g. Orapa-Letlhakane, Jwaneng, Premier). Correlation of the seismically slow regions of the northern Kaapvaal Craton that trend ESE-WNW south of the Limpopo belt (Fig. 1) with surface outcrop of the $2.05 \mathrm{Ga}$ Bushveld Complex in South Africa and Molopo Farms Complex in Botswana suggests that the modification may be closely related to Bushveld-Molopo magmatism. For the seismically slow mantle that trends N-S on the west side of the Zimbabwe craton (Fig. 1), regional metamorphism that created the Mogondi-Okwa terranes was likely to have been the surface manifestation of the tectonism that modified the craton on this margin.

Thermal structure of the Kaapvaal lithospheric mantle from surface heat flow (Jones, 1988) and cratonic geotherms from Premier xenoliths (Danchin, 1979) show that in at least one part of the seismically slow lithosphere a normal cratonic geotherm has existed since $1.2 \mathrm{Ga}$. This is key evidence that the lithosphere is seismically slower chiefly because it is compositionally different (e.g. higher in basaltic components and metasomatizing veins), not hotter. Diamond suites from seismically slower lithosphere have a greater percentage of eclogitic inclusions which are in direct agreement with regions of the lithosphere that would have a higher proportion of basaltic components.

Cratonic nuclei were first created by mantle melting processes that produced severe depletion of the lithospheric mantle (Richardson et al., 1984) and an early phase of crustal differentiation. The existence of these early cratonic nucleii could have provided a locus against which to accrete cratonic lithosphere created in the second step of the process (Shirey et al., 2002). In this phase, subduction, which may have included depleted oceanic harzburgite and/or the roots of Archean oceanic plateaus, built the rest of the lithospheric mantle. A second phase of lithosphere creation such as this could account for many geochemical features of the lithospheric mantle. This two-step lithosphere creation model also fits the detailed geochronological record for the lower and upper crust of the western Kaapvaal craton in which the earliest crustal components are formed from 3.20-3.26 $\mathrm{Ga}$ and the craton is sutured together by subduction convergence at 2.88-2.94 Ga (Schmitz, 2002).

Subduction for the western craton is supported by stable isotopic data from Orapa and Jwaneng. Orapa E-Type diamonds have light $\mathrm{C}$ and heavy $\mathrm{N}$ isotopic compositions (Cartigny et al., 1999) and sulfide 
inclusions with mass-independent sulfur isotopic fractionations (Farquhar et al., 2002). These signatures are consistent with incorporation of $\mathrm{C}, \mathrm{N}$, and $\mathrm{S}$ from surficial sedimentary endmember reservoirs (Navon, 1999; Farquhar et al., 2002) even though intra-mantle fractionation (e.g. Cartigny et al., 2001) that changed $\mathrm{C}$ and $\mathrm{N}$ isotopic composition of fluids during diamond growth, are required.

The near one-to-one correspondence of Proterozoic diamond suites having a majority of E-Type silicate inclusions with seismically slow mantle suggests that craton modification and Proterozoic diamond formation were part of the same process that involved basaltic components. These were generated in conjunction with Bushveld-Molopo Farms magmatism under the center of the northern Kaapvaal craton or in conjunction with some form of subduction along the western KaapvaalZimbabwe craton margin (Shirey et al., 2002). Both sublithospheric magmatism and western craton margin subduction were tectonothermal events that altered the composition of the lithosphere and added new diamonds to an already extensive Archean diamond population resident in the lithosphere.

\section{APPLICATION TO NEW AREAS AND OTHER CRATONS}

The correlation of existing diamond age, composition and inclusion paragenesis data with lithospheric seismic structure provides a set of predictions that can be applied to future diamond studies: a) the eastern domain of the Kaapvaal-Zimbabwe craton should have its own clustering of diamond ages that are systematically older than those in the western domain, b) new suites of PType inclusions should be 3.2 Ga old or greater and be rare outside of seismically fast lithosphere, c) additional suites of E-Type diamonds should be widely distributed in all domains of the craton, and d) Proterozoic diamonds from the seismically slower part of the lithosphere might be expected to have the greatest range in age and composition.

Inclusion paragenesis versus age shows a remarkable similarity from craton to craton. The oldest inclusions yet dated on the Kaapvaal-Zimbabwe, Siberian and Slave craton are all P-Types (harzburgitic silicate or sulfides) in the 3.2-3.4 Ga age range (Richardson et al., 1984; Pearson et al., 1999a; Westerlund, this volume; Pearson et al., 1999b). Both the Kaapvaal-Zimbabwe craton and the Siberian craton have abundant $2.9 \mathrm{Ga}$ eclogitic components associated with diamonds (Pearson et al., 1995; Shirey et al., 2001; Shirey et al.,
2003). Both cratons have a Proterozoic, lherzolitic silicate inclusion suite that has a negative initial epsilon Nd yielding Archean model ages (Richardson et al., 1993; Richardson and Harris, 1997; Richardson et al. this volume). These similarities in age and paragenesis of diamond suites among cratons that are now so widely separated may indicate that diamond formation on the Archean Earth was controlled by global scale events in mantle/crustal evolution and/or that Kaapvaal/Zimbabwe, Siberian, Slave, and Australian cratons were situated close together in an Archean supercontinent that may have become disassembled by the mid-Proterozoic.

\section{REFERENCES}

Carlson, R.W., Boyd, F.R., Shirey, S.B., Janney, P.E., Grove, T.L., Bowring, S.A., Schmitz, M.D., Dann, J.C., Bell, D.R., Gurney, J.J., Richardson, S.H., Tredoux, M., Menzies, A.H., Pearson, D.G., Hart, R.J., Wilson, A.H. and Moser, D., 2000. Continental growth, preservation, and modification in southern Africa. GSA Today, 10: $1-7$.

Carlson, R.W., Pearson, D.G., Boyd, F.R., Shirey, S.B., Irvine, G., Menzies, A.H. and Gurney, J.J., 1999. ReOs systematics of lithospheric peridotites: implications for lithosphere formation and preservation. In: J.J. Gurney, J.L. Gurney, M.D. Pascoe and S.H. Richardson (Editors), The J. B. Dawson Volume Proceedings of the Seventh International Kimberlite Conference, Cape Town. Red Roof Design, Cape Town, pp. 99-108.

Cartigny, P., Harris, J.W. and Javoy, M., 1999. Eclogitic, peridotitic and metamorphic diamonds and the problems of carbon recycling - the case of Orapa (Botswana). In: J.J. Gurney, J.L. Gurney, M.D. Pascoe and S.H. Richardson (Editors), The J.B. Dawson Volume - Proceedings of the Seventh International Kimberlite Conference, Cape Town. Red Roof Design, Cape Town, pp. 117-124.

Cartigny, P., Harris, J.W. and Javoy, M., 2001. Diamond genesis, mantle fractionations and mantle nitrogen content: a study of $\delta^{13} \mathrm{C}-\mathrm{N}$ concentrations in diamonds. Earth and Planetary Science Letters, 185: 85-98.

Danchin, R.V., 1979. Mineral and bulk chemistry of garnet lherzolite and garnet harzburgite xenoliths from the Premier Mine, South Africa. In: F.R. Boyd and H.O.A. Meyer (Editors), The mantle sample: inclusions in kimberlites and other volcanics, Proceedings of the Second International Kimberlite Conference, Santa Fe. American Geophysical Union, Washington, pp. 104126.

Deines, P., Harris, J.W. and Gurney, J.J., 1993. Depth-related carbon isotope and nitrogen concentration variability in the mantle below the Orapa Kimberlite, Botswana, Africa. Geochim Cosmochimica Acta, 57: 2781-2796.

Deines, P., Harris, J.W. and Gurney, J.J., 1997. Carbon isotope ratios, nitrogen content and aggregation state, 
and inclusion chemistry of diamonds from Jwaneng, Botswana. Geochimica et Cosmochimica Acta, 61: 3993-4005.

Deines, P., Harris, J.W., Spear, P.M. and Gurney, J.J., 1989. Nitrogen and ${ }^{13} \mathrm{C}$ content of Finsch and Premier diamonds and their implications. Geochimica et Cosmochimica Acta, 53: 1367-1378.

Farquhar, J., Wing, B.A., McKeegan, Harris, J.W., Cartigny, P. and Thiemens, M., 2002. Mass-independent sulfur in inclusions in diamond and sulfur recycling on early Earth. Science, 298: 2369-2372.

Irvine, G.J., Pearson, D.G. and Carlson, R.W., 2001. Lithospheric mantle evolution of the Kaapvaal craton: A Re-Os isotope study of peridotite xenoliths from Lesotho kimberlites. Geophysical Research Letters, 28: 2505-2508.

Jones, M.Q.W., 1988. Heat flow in the Witwatersrand Basin and environs and its significance for the south African shield geotherm and lithosphere thickness. Journal of Geophysical Research, 93: 3243-3260.

Kirkley, M.B., Gurney, J.J. and Levinson, A.A., 1991. Age, origin, and emplacement of diamonds; scientific advances in the last decade. Gems and Gemology, 27: $2-25$.

Kramers, J.D., 1979. Lead, uranium, strontium, potassium and rubidium in inclusion-bearing diamonds and mantlederived xenoliths from southern Africa. Earth and Planetary Science Letters, 42: 58-70.

Moser, D.E., Flowers, R. and Hart, R.J., 2000. Birth of the Kaapvaal lithosphere at $3.08 \mathrm{Ga}$; implications for the growth of ancient continents. Science, 291: 465-468.

Navon, O., 1999. Diamond formation in the Earth's mantle. In: J.J. Gurney, J.L. Gurney, M.D. Pascoe and S.H. Richardson (Editors), The P.H. Nixon Volume Proceedings of the Seventh International Kimberlite Conference, Cape Town. Red Roof Design, Cape Town, pp. 584-604.

Pearson, D.G., Shirey, S.B., Bulanova, G.P., Carlson, R.W. and Milledge, H.J., 1999a. Re-Os isotope measurements of single sulfide inclusions in a Siberian diamond and its nitrogen aggregation systematics. Geochimica et Cosmochimica Acta, 63: 703-711.

Pearson, D.G., Shirey, S.B., Bulanova, G.P., Carlson, R.W. and Milledge, H.J., 1999b. Dating and paragenetic distinction of diamonds using the Re-Os isotope system; application to some Siberian diamonds. In: J. Gurney John, L. Gurney James, D. Pascoe Michelle and H. Richardson Stephen (Editors), The P. H. Nixon Volume. Proceedings of the International Kimberlite Conference. 7, Vol. Red Roof Design, Cape Town, pp. 637-643.

Pearson, D.G., Shirey, S.B., Harris, J.W. and Carlson, R.W., 1998. Sulfide inclusions in diamonds from the Koffiefontein kimberlite, S. Africa: Constraints on diamond ages and mantle Re-Os systematics. Earth and Planetary Science Letters, 160: 311-326.

Pearson, D.G., Snyder, G.A., Shirey, S.B., Taylor, L.A., Carlson, R.W. and Sobolev, N.V., 1995. Archaean ReOs age for Siberian eclogites and constraints on Archaean tectonics. Nature, 374: 711-713.

Richardson, S.H., 1986. Latter-day origin of diamonds of eclogitic paragenesis. Nature, 322: 623-626.
Richardson, S.H., Chinn, I.L. and Harris, J.W., 1999. Age and origin of eclogitic diamonds from the Jwaneng kimberlite, Botswana. In: J.J. Gurney, J.L. Gurney, M.D. Pascoe and S.H. Richardson (Editors), The P. H. Nixon Volume - Proceedings of the Seventh International Kimberlite Conference, Cape Town. Red Roof Design, Cape Town, pp. 734-736.

Richardson, S.H., Erlank, A.J., Harris, J.W. and Hart, S.R., 1990. Eclogitic diamonds of Proterozoic age from Cretaceous kimberlites. Nature, 346: 54-56.

Richardson, S.H., Gurney, J.J., Erlank, A.J. and Harris, J.W., 1984. Origin of diamonds in old enriched mantle. Nature, 310: 198-202.

Richardson, S.H. and Harris, J.W., 1997. Antiquity of peridotitic diamonds from the Siberian craton. Earth and Planetary Science Letters, 151: 271-277.

Richardson, S.H., Harris, J.W. and Gurney, J.J., 1993. Three generations of diamonds from old continental mantle. Nature, 366: 256-258.

Richardson, S.H., Shirey, S.B., Harris, J.W. and Carlson, R.W., 2001. Archean subduction recorded by Re-Os isotopes in eclogitic sulfide inclusions in Kimberley diamonds. Earth and Planetary Science Letters, 191: 257-266.

Schmitz, M.D., 2002. Geology and thermochronology of the lower crust of southern Africa. PhD Thesis, Massachusetts Institute of Technology, Cambridge, $269 \mathrm{pp}$.

Shirey, S.B., Carlson, R.W., Richardson, S.H., Menzies, A.H., Gurney, J.J., Pearson, D.G., Harris, J.W. and Wiechert, U., 2001. Archean emplacement of eclogitic components into the lithospheric mantle during formation of the Kaapvaal Craton. Geophysical Research Letters, 28: 2509-2512.

Shirey, S.B., Harris, J.W., Richardson, S.H., Fouch, M.J., James, D.E., Cartigny, P., Deines, P. and Viljoen, F., 2002. Diamond genesis, seismic structure, and evolution of the Kaapvaal-Zimbabwe craton. Science, 297: 1683-1686.

Shirey, S.B., Harris, J.W., Richardson, S.H., Fouch, M.J., James, D.E., Cartigny, P., Deines, P. and Viljoen, F., 2003. Regional patterns in the paragenesis and age of inclusions in diamond, diamond composition and the lithospheric seismic structure of southern Africa. In: R.W. Carlson, H. Grutter and A.G. Jones (Editors), Slave-Kaapvaal Workshop, Merrickville, Ontario.

Smith, C.B., Gurney, J.J., Harris, J.W., Robinson, D.N., Kirkley, M.B. and Jagoutz, E., 1991. Neodymium and strontium isotope systematics of eclogite and websterite paragenesis inclusions from single diamonds. Geochimica et Cosmochimica Acta, 55: 2579-2590.

Sobolev, N.V., Galimov, E.M., Ivanovskaya, I.N. and Yefimova, E.S., 1979. The carbon isotope composition of diamonds containing crystalline inclusions. Doklady Akademy Nauk USSR, 189: 133-136.

Contact: SB Shirey, Department of Terrestrial Magnetism,

Carnegie Institution of Washington, 5241 Broad Branch

Road, NW, Washington, DC, 20015, USA, E-mail:

shirey@dtm.ciw.edu 